\title{
Applications of Cytosorb in clinical practice
}

\author{
Paweł Kutnik ${ }^{1 \oplus}$, Michał Borys ${ }^{2 \oplus}$ \\ 'Student's Scientific Association, II Department of Anaesthesiology and Intensive Care, Medical University, Lublin, Poland \\ 2 II Department of Anaesthesiology and Intensive Care, Medical University, Lublin, Poland \\ A - Research concept and design, B - Collection and/or assembly of data, C - Data analysis and interpretation, \\ $D$ - Writing the article, E - Critical revision of the article, F - Final approval of article
}

Kutnik P, Borys M. Applications of Cytosorb in clinical practice. J Pre-Clin Clin Res. 2019; 13(4): 162-166. doi: 10.26444/jpccr/112882

\begin{abstract}
Introduction and objective. Cytososorb is haemadsorption device approved in the European Union in 2011 for cytokine adsorption. Recently, in 2018, new indications for the device use have been added, including bilirubin and myoglobin removal. This study aimed to present the results of studies pertaining to Cytosorb use in clinical practice. In subsequent sections of this review, indications for Cytosorb therapy and clinical relevance of presented evidence are listed.

State of knowledge. In clinical practice, Cytosorb has been reported as one of potential supportive therapies in patients with septic shock. There is evidence of significant reduction of interleukin 6 and vasopressors when Cytosorb is implemented. However, the decreased mortality after Cytosorb has yet to be reported. Besides cytokine adsorption, Cytosorb also collects drugs, a property that can have a beneficial effect on acute drug poisoning (anticoagulants). However, Cytosorb lowers the plasma concentration of some antibiotics which might affect the outcome of patients in septic shock. The haemadsorption device has also been researched in cardiac patients, and some reports suggest a reduced need for vasopressors and blood transfusions when therapy is installed during surgery. Other indications for Cytosorb are also reported, especially the effectiveness in decreasing bilirubin serum concentrations as treatment or bridge therapy, without affecting the albumins. Cytosorb might also be the last resort treatment in acquired haemophagocytic lymphohistiocytosis.

Conclusions. The evidence supporting the use of CytoSorb remains elusive. There is lack of large prospective studies which could provide definitive answers about the place of Cytosorb in clinical practice. There are no reports of safety and feasibility issues in all presented studies.
\end{abstract}

Key words

Critical care, ICU, haemadsorption, blood purification, Cytosorb

\section{INTRODUCTION AND OBJECTIVE}

Haemadsorption is a process in which an artificial device is placed in an extracorporeal circuit and used to bind different types of solutes from the blood. The haemadsorption devices can be connected to renal replacement therapy machines, extracorporeal membrane oxygenator, or cardiopulmonary bypass equipment. There are different haemadsorption devices on the market, including Cytosorb, oXiris or Toramyxin. The first results of in vitro studies comparing these devices suggest there might be different applications for each of the adsorbents [1]. This review evaluates the reports and studies about Cytosorb.

Cytosorb is a haemoadsorption device used as one of the extracorporeal blood purification techniques. The device was approved for the management of inflammatory conditions in 2011 and the registry was extended in 2018 to the treatment of high bilirubin or myoglobin concentrations. Cytosorb consists of adsorption columns made from biocompatible, highly porous polymer, with an estimated surface area over 40,000 square meters. The device targets the molecules with a wide range of size up to $60 \mathrm{kDa}$. One cycle of therapy usually takes 24 hours with blood flow set between 100$700 \mathrm{~mL} / \mathrm{min}$., and is reported as being performed daily for up to 7 consecutive days [2].

Adress for correspondence: Paweł Kutnik, Student's Scientific Association, II Department of Anaesthesiology and Intensive Care, Medical University of Lublin, Lublin, Poland

E-mail: pe.kutnik@gmail.com

Received: 08.07.2019; accepted: 08.10.2019; first publisched: 31.12 .2019
Due to Cytosorb being a relatively novel device, it is constantly researched and new applications being discovered. With 73 articles in the PubMed database and over 450 research and report documents in the Cytosorb literature database, a summary of these publications is required [3]. The aim of this article was to present and recap some of the reports about the use of CytoSorb in various clinical scenarios.

\section{STATE OF KNOWLEDGE}

Cytosorb as cytokine remover. Cytosorb was primarily presented as the cytokine remover, mainly designed for patients with severe septic shock or systemic inflammatory response syndrome. The reasoning behind using a haemoadsorption device in the inflammatory process is to remove the pro-inflammatory cytokines to prevent further damage and regain the patient's haemodynamic stability [4]. Additionally, the use of a haemoadsorption device could have a beneficial impact by promoting the protection of the vascular barrier [5]. In in vitro studies, Cytosorb was proved to reduce the concentrations not only of cytokines, but also pathogen-associated molecular pattern molecules, including bacterial exotoxins which are considered triggers of an immune reponse[6]. Early reports on using Cytosorb showed promising results, including reduction of vasopressors with haemodynamic stabilization and reduction of capillary leakage[7]. The majority of the more prominent studies in septic shock patients present similar results confirming the reduction of vasopressor dose, with the regaining of 
Table 1. Cytosorb in septic shock studies

\begin{tabular}{|c|c|c|c|c|}
\hline Study & Type of study & No. of patients & Reason for $\mathrm{HA}$ & Conclusions \\
\hline Friesecke et al., 2017a [9] & $\begin{array}{l}\text { Prospective, } \\
\text { interventional, single- } \\
\text { centre investigation }\end{array}$ & 20 & Septic shock & $\begin{array}{l}\text { Significant reduction of noradrenaline after HA introduction, } \\
\text { improved lactate clearance, septic shock reversal in } 65 \% \text { of } \\
\text { patients. }\end{array}$ \\
\hline Kogelmann et al., 2017 [12] & Case series & 26 & Septic shock & $\begin{array}{l}\text { Haemodynamic stabilization and reduction in blood lactate } \\
\text { levels. Actual mortality lower than mortality predicted, based } \\
\text { on APACHE II score. }\end{array}$ \\
\hline Friesecke et al., 2017b [11] & $\begin{array}{l}\text { International registry } \\
\text { preliminary results }\end{array}$ & 198 & $\begin{array}{l}\text { Sepsis ( } 135 \text { patients). } \\
\text { Intra- and post-operative } \\
\text { cardiac surgery ( } 25 \text { patients). } \\
\text { Other indication ( } 38 \text { patients) }\end{array}$ & $\begin{array}{l}\text { Reduced interleukin- } 6 \text { levels after treatment, compared to pre- } \\
\text { treatment levels. Lower observed mortality } 65 \% \text { vs. predicted } \\
\text { mortality, based on APACHE II score of } 78 \% \text {. }\end{array}$ \\
\hline Shädler et al., 2017 [13] & $\begin{array}{l}\text { Prospective, randomized, } \\
\text { controlled tal }\end{array}$ & $\begin{array}{l}97 \text { (47 vs. } 50 \\
\text { control) }\end{array}$ & Septic shock & $\begin{array}{l}\text { Significant interleukin- } 6 \text { elimination. After adjustment for } \\
\text { patient morbidity and baseline imbalances, no difference in } \\
\text { mortality found between groups. }\end{array}$ \\
\hline Tomescu et al., 2019 [10] & Case series & 12 & Severe acute pancreatitis & $\begin{array}{l}\text { Use of HA was associated with improved hemodynamics and } \\
\text { decreased inflammatory markers. }\end{array}$ \\
\hline Hawchar et al., 2019 [8] & $\begin{array}{l}\text { Prospective, randomized, } \\
\text { controlled pilot study }\end{array}$ & $\begin{array}{l}20 \text { (10 vs. } 10 \\
\text { control) }\end{array}$ & Septic shock & $\begin{array}{l}\text { Significantly decreased norepinephrine requirements, } \\
\text { procalcitonin, and Big-endothelin-1 concentrations. }\end{array}$ \\
\hline
\end{tabular}

HA - haemadsorption; APACHE II - Acute Physiology, Age, Chronic Health Evaluation II

haemodynamic stability after implementation of the haemadsorption device [Tab. 1] [8]. Interleukin- 6 and lactates are cleared significantly during the treatment [9]. A study in a population with septic shock due to severe acute pancreatitis showed similar results [10]. A retrospective study of patients in the International Registry showed a reduction in observed mortality compared to the predicted mortality from $78 \%$ to $65 \%$ [11]. A similar observation was presented in a case series study performed by Kogelmann [12]. Although significant interleukin- 6 reduction was observed, the only randomized prospective trial showed no significantly reduced mortality in patients supported with Cytosorb[13].

Cytosorb in drug removal. Although Cytosorb was designed primarily to remove inflammatory cytokines, it is not a selective adsorber. In 2002, an in vitro study of a similar device, BetaSorb, showed significant clearance of some drugs [Tab. 2] [14]. Although Cytosorb is a different device, this study is used by the manufacturer as a reference for antibiotic guidance for Cytosorb. The in vitro pharmacokinetic study performed by König et al. in 2019 estimated that one Cytosorb device absorbs approximately $400 \mathrm{mg}$ of meropenem and $300 \mathrm{mg}$ of ciprofloxacin [15]. Considering haemoadsorption is used during septic shock, where antibiotics play a major role in treatment, the impact of removal of some antibiotics should be carefully evaluated. An inadequate, too low dose of antibiotics is associated with treatment failure [16] and the development of drug resistance in bacteria [17]. If possible, monitoring of the antibiotics serum concentration should be routinely performed when using Cytosorb. Due to the lack of in vivo pharmacokinetic model studies, a guideline for routine increase of the antibiotics remains elusive. The two case reports in vivo pharmacokinetics showed a significant removal of linezolid, potential significant removal of meropenem, and no impact on clindamycin clearance[18, 19].

The non-selectivity of Cytosorb can be used as an advantage, as presented in a case from 2019, when haemadsorption with continuous renal replacement therapy was successfully used in the treatment of quetiapine overdose [20]. Cytosorb was also reported to significantly remove the ticagrelor and rivaroxaban, which can potentially lead to thrombotic complications, such as acute myocardial infarction or stroke.
However, in the case of severe bleeding due to those drugs, it could be used as a treatment option. In a study by Hassan et al., the use of Cytosorb during emergency cardiac surgeries was presented as likely to be beneficial in patients treated with ticagrelor or rivaroxaban [21]. In a retrospective study, Cytosorb significantly reduced the number of transfusions of red blood cell units and platelets concentrate units, shortened the ICU stay and lowered the frequency of re-thoracotomy. If confirmed in prospective studies, this approach could become routine in emergency cardiac operations. There is a need for further studies on drugs affected by the haemoadsorption device, and the clinical significance of drugs removal.

Cytosorb in cardiac surgery. Cardiac surgery procedures are often associated with a huge release of cytokines and the development of systemic inflammatory response [22]. The reasoning behind the use of Cytosorb is to adsorb those cytokines before the systemic response sets in. Case series and retrospective studies have shown promising results [Tab. 3]. Less vasopressor was needed during the operation, and fewer renal replacement therapy implemented after the surgery in patients who used Cytosorb connected to the cardiopulmonary by-pass $[23,24]$. In a study performed by Gleason et al., patients with haemoadsorption had a significantly lower free haemoglobin and activated complement serum concentrations [25].

A study published in 2019 by Saller et al. on 336 patients with 168 undergoing haemoadsorption in aortic surgeries, showed not only a significantly reduced need for vasopressors, but also the amount of perioperative transfusion, and positive impact on acid-base balance [26]. The case series comparing intraoperative vs. intraoperative and postoperative use of Cytosorb showed that more intense therapy (intra-operative and post-operative) might be associated with patient improvement [27]. However, two prospective, randomized, blind and controlled trials did not confirm the previous results $[28,29]$. There was no significant difference in inflammatory markers, blood substitution, vasopressor need or mortality. Without large, multicentred prospective trials, the impact of haemadsorption in cardiac surgery remains elusive. 
Table 2. Cytosorb in drug studies

\begin{tabular}{llll}
\hline \multicolumn{1}{c}{ Study } & Type of study & \multicolumn{1}{c}{ Additional Information } \\
\hline Reiter et al., 2002 [14] & In vitro & $\begin{array}{l}\text { Tested on BetaSorb, study provided as information } \\
\text { on official CytoSorb website. }\end{array}$ & $\begin{array}{l}\text { HA was associated with significant removal of antibiotics (Vancomycin, } \\
\text { Teicoplanin), Valproic acid, Phenobarbital, Carbamazepine, Phenytoin, } \\
\text { Digoxin and Cyclosporine. HA did not affect aminoglycosides clearance. }\end{array}$ \\
\hline Zoller et al., 2015 [18] & Case report & Patient with septic shock, Cytosorb & $\begin{array}{l}\text { Cytosorb was associated with significant removal of linezolid. Effects of } \\
\text { Cytosorb on meropenem remained elusive as blood samples were not } \\
\text { collected at optimal time points. }\end{array}$ \\
\hline König et al., 2019 [15] & In vitro & $\begin{array}{l}\text { Tested on Cytosorb, clearance was established in } \\
\text { normal saline, human albumin and reconstituted } \\
\text { blood solutions }\end{array}$ & $\begin{array}{l}\text { Cytosorb had significant clearance for meropenem and ciprofloxacin } \\
\text { during early course of adsorption. Approximately 400 mg of meropenem } \\
\text { and 300 mg of ciprofloxacin absorbed by CytoSorb. }\end{array}$ \\
\hline Poli et al., 2019a [19] & Case report & $\begin{array}{l}\text { Patient with Panton-Valentine leucocidin MRSA } \\
\text { and Influenza B infectionrequiring ECMO support }\end{array}$ & \begin{tabular}{l} 
Cytosorb did not have significant impact on clindamycin removal. \\
\hline Giuntoli et al., 2019 [20]
\end{tabular} \\
& Case report & $\begin{array}{l}\text { Symptomatic voluntary overdose treated with } \\
\text { CRRT and CytoSorb }\end{array}$ & $\begin{array}{l}\text { HA with CRRT was safe and successful approach in treatment of severe } \\
\text { quetiapine overdose. }\end{array}$
\end{tabular}

Hassan et al., 2019 [21] Retrospective 55 consecutive patients treated with Ticagrelor study $\quad(\mathrm{N}=43)$ or Rivaroxaban $(\mathrm{N}=12)$ undergoing emergency cardiac operations. 39 patients had routinely installed Cytosorb
Use of HA during procedure was associated with significantly shorter operation time, lower drainage volume, fewer transfusions of PRBCs and PC, lower re-thoracotomy rate, and shorter stay in ICU.

HA - hemadsorption; CRRT - continuous renal replacement therapy; ECMO - extracorporeal membrane oxygenation; PRBC - pack red blood cells; PC - packed cells; ICU - intensive care unit; MRSA - methicillin-resistant Staphylococcus aureus;

Table 3. Cytosorb in cardiac surgeries

\begin{tabular}{|c|c|c|c|c|}
\hline Study & Type of study & Population & Procedure & Conclusions \\
\hline Bernardi et al., 2016 [28] & $\begin{array}{l}\text { Prospective, blind, } \\
\text { randomized }\end{array}$ & $\begin{array}{l}37 \text { ( } 19 \mathrm{HA} \text { vs. } \\
18 \text { control) }\end{array}$ & Different cardiothoracic surgeries & $\begin{array}{l}\text { No difference between intervention and control group in } \\
\text { inflammatory markers, blood substitution, vasopressor use or } \\
\text { mortality. }\end{array}$ \\
\hline Träger et al., 2017 [23] & Case series & $\begin{array}{l}57 \text { ( } 39 \mathrm{HA} \text { vs. } \\
28 \text { control) }\end{array}$ & $\begin{array}{l}\text { Valve replacement due to acute } \\
\text { endocarditis }\end{array}$ & Patient with HA had less pronounced need for vasopressors. \\
\hline Nemeth et al., 2018 [24] & $\begin{array}{l}\text { Observational } \\
\text { study }\end{array}$ & $\begin{array}{l}84 \text { ( } 24 \mathrm{HA} \text { vs. } \\
60 \text { control) }\end{array}$ & Orthotopic heart transplantation & $\begin{array}{l}\text { Patient with HA had reduced vasopressor demand and less } \\
\text { frequent renal replacement therapy. }\end{array}$ \\
\hline Kuhne et al., 2019 [27] & Case series & $20 \mathrm{HA}$ & $\begin{array}{l}\text { Intraoperative (10) vs. intra-plus } \\
\text { postoperative haemadsorption (10) }\end{array}$ & $\begin{array}{l}\text { Similar intensive care unit and } 90 \text {-day survival despite patient } \\
\text { with intra-plus postoperative HA had longer ICU stay and higher } \\
\text { rate of postoperative complications }\end{array}$ \\
\hline Poli et al., 2019b [29] & $\begin{array}{l}\text { Prospective, } \\
\text { randomized, } \\
\text { controlled trial }\end{array}$ & $\begin{array}{l}30 \text { ( } 15 \text { HA vs. } \\
15 \text { control) }\end{array}$ & Different cardiothoracic surgeries & $\begin{array}{l}\text { No difference in decrease of pro- or anti-inflammatory cytokines } \\
\text { and lack of improvement in relevant clinical outcomes. }\end{array}$ \\
\hline Saller et al., 2019 [26] & $\begin{array}{l}\text { Retrospective, } \\
\text { single-centre } \\
\text { experience }\end{array}$ & $\begin{array}{l}336 \text { ( } 168 \mathrm{HA} \text { vs. } \\
168 \text { control })\end{array}$ & Aortic surgeries & $\begin{array}{l}\text { Patient with HA had significantly reduced need for vasopressors, } \\
\text { amount of transfusions and improved acid-base balance. }\end{array}$ \\
\hline Gleason et al., 2019 [25] & $\begin{array}{l}\text { Prospective, } \\
\text { randomized, } \\
\text { controlled trial }\end{array}$ & $\begin{array}{l}38 \text { ( } 18 \text { HA vs. } \\
20 \text { control) }\end{array}$ & $\begin{array}{l}\text { Cardiopulmonary bypass, elective, } \\
\text { non-emergent, complex cardiac } \\
\text { surgeries }\end{array}$ & $\begin{array}{l}\text { Significant reduction in free haemoglobin and activated } \\
\text { complement in HA group. }\end{array}$ \\
\hline
\end{tabular}

HA - haemadsorption; ICU - intensive care unit

Cytosorb in other applications. As mentioned above, Cytosorb is not a selective adsorber, therefore, other molecules can be eliminated by the device. The most-reported uses are associated with bilirubin and bile acids removal. Cytosorb is a whole blood adsorbent without the need for prior plasma separation, which can be useful in albuminbound molecules such as bilirubin and bile acids [30]. The conjugated bilirubin is a relatively small, water-soluble molecule, therefore it is easily absorbed by the device. On the other hand, unconjugated bilirubin, despite also being a relatively small molecule, is not water-soluble and is bounded to albumin particles, which are bigger than the maximum range of Cytosorb. The device breaks the binding between unconjugated bilirubin and albumin, allowing the device to absorb the bilirubin molecule without affecting patients' albumin serum concentrations. The in vitro study from 2018 confirmed bilirubin removal by Cytosorb without affecting the albumin serum concentration during the process, which was a therapeutic issue with some other methods [31]. The case of cardiac surgery patient showed a bilirubin drop from $24.5 \mathrm{mg} / \mathrm{dL}$ to $10.8 \mathrm{mg} / \mathrm{dL}$ after three days of Cytosorb therapy[32]. The Cytosorb was reported to be useful in patient with hyperbilirubinemia due to hepatic failure [33], in drug-induced cholestasis, alcoholic hepatitis [34], and cholestasis in sepsis [35]. It was used successfully in a liver cirrhosis patient with a pre-existing hepatitis $\mathrm{C}$ infection [36]. Additionally, in that paper, the authors reported a significant reduction in ammonia levels, which might be used in the treatment of severe hyperammonaemia in liver failure patients. However, this requires further investigation 
and caution, as the Cytosorb device is not registered for reducing ammonia levels.

Cytosorb was reported to be successful in a $9 \mathrm{~kg}$ paediatric patient, with a decrease in total bilirubin concentration from $54 \mathrm{mg} / \mathrm{dL}$ to $17 \mathrm{~g} / \mathrm{dL}$ after a 24-hour cycle with blood flow set at $40 \mathrm{~mL} / \mathrm{h}$ [37]. The largest case series study published in 2019, included 40 patients with different primary diseases, mainly cardiac. The study showed a significant reduction in bilirubin, lactates, creatine phosphokinase and lactate dehydrogenase serum concentrations [38]. To our knowledge, there are no results of studies comparing the effectiveness of Cytosorb with other methods used to lower bilirubin serum concentration.

Cytosorb was also reported as an additional support in three patients with acquired haemophagocytic lymphohistiocytosis $[39,40]$, a disease caused by the production of too many immune cells activated by a 'cytokine storm'. The disease has a more than $50 \%$ mortality rate [41]. The reasoning behind using haemadsorption is to remove the cytokine that activates the immune cells, and potentially stop the disease. Cytosorb could be considered as last resort treatment option in patients with acquired haemophagocytic lymphohistiocytosis refractory to other treatments.

\section{CONCLUSIONS}

Cytosorb could become a useful tool in clinical practice, but the evidence supporting that theory remains elusive due to the lack of large prospective trials. The enrollment in such trials is challenging due to the extreme heterogeneity of the patient population, especially those in septic shock. The impact of haemoadsorption on drugs clearance should be further evaluated to ensure the optimal dosing of drugs during the therapy. Cytosorb might be a useful device in patients with liver impairment, helping to regain liver function or serve as a bridge therapy to the liver transplant. There is no strong evidence from prospective trials reporting the benefits of Cytosorb use in cardiothoracic surgeries. However, there is no report on the safety and feasibility issues in all presented studies; therefore, applications of the device should be further researched to produce definitive results.

The authors declare no conflict of interest. The study had no external funding.

\section{REFERENCES}

1. Malard B, Lambert C, Kellum JA. In vitro comparison of the adsorption of inflammatory mediators by blood purification devices. Intensive Care Med Exp. 2018; 6(1): 12. https://doi.org/10.1186/s40635-018-0177-2 2.https://cytosorbents.com/products/cyto-sorb/ [6.07.2019]

3.https://literature.cytosorb-therapy.com/ [6.07.2019]

4. Gogos CA, Drosou E, Bassaris HP, Skoutelis A. Pro- versus antiinflammatory cytokine profile in patients with severe sepsis: a marker for prognosis and future therapeutic options. J Infect Dis. 2000; 181(1): 176-180. https://doi.org/10.1086/315214

5. David S, Thamm K, Schmidt BMW, Falk CS, Kielstein JT. Effect of extracorporeal cytokine removal on vascular barrier function in a septic shock patient. J Intensive Care. 2017; 5: 12. doi:10.1186/s40560017-0208-1

6. Gruda MC, Ruggeberg K-G, O’Sullivan P, Guliashvili T, Scheirer AR, Golobish TD, et al. Broad adsorption of sepsis-related PAMP and DAMP molecules, mycotoxins, and cytokines from whole blood using CytoSorb $^{\star}$ sorbent porous polymer beads. PLoS ONE 2018; 13(1): e0191676. https://doi.org/10.1371/journal.pone.0191676
7. Hinz B, Jauch O, Noky T, Friesecke S, Abel P, Kaiser R. CytoSorb, a novel therapeutic approach for patients with septic shock: a case report. Int J Artif Organs. 2015; 38(8): 461-464. https://doi.org/10.5301/ijao.5000429 8. Hawchar F, László I, Öveges N, Trásy D, Ondrik Z, Molnar Z. Extracorporeal cytokine adsorption in septic shock: a proof of concept randomized, controlled pilot study. J Crit Care. 2019; 49: 172-178. https://doi.org/10.1016/j.jcrc.2018.11.003

9. Friesecke S, Stecher SS, Gross S, Felix SB, Nierhaus A. Extracorporeal cytokine elimination as rescue therapy in refractory septic shock: a prospective single-center study. J Artif Organs 2017; 20: 252-259. https:// doi.org/10.1007/s10047-017-0967-4

10. Tomescu D, Popescu M, David C, \& Dima S. Clinical effects of hemoadsorption with CytoSorb ${ }^{\star}$ in patients with severe acute pancreatitis: A case series. Int J Artif Organs 2019; 42(4): 190-193. https:// doi.org/10.1177/0391398818823762

11. Friesecke S, Träger K, Schittek GA, Molnar Z, Bach F, Kogelmann K, et al. International registry on the use of the CytoSorb adsorber in ICU patients: study protocol and preliminary results. Med Klin Intensivmed Notfmed. 2017. https://doi.org/10.1007/s00063-017-0342-5

12. Kogelmann K, Jarczak D, Scheller M, Druner M. Hemoadsorption by CytoSorb in septic patients: a case series. Crit Care 2017; 21(1): 74. https://doi.org/10.1186/s13054-017-1662-9

13. Schädler D, Pausch C, Heise D, Meier-Hellmann A, Brederlau J, Weiler $\mathrm{N}$, et al. The effect of a novel extracorporeal cytokine hemoadsorption device on IL- 6 elimination in septic patients: A randomized controlled trial. PLoS One 2017; 12(10): e0187015. https://doi.org/10.1371/journal. pone. 0187015

14. Reiter K, Bordoni V, Dall'Olio G, Ricatti MG, Soli M, Ruperti S, et al. In vitro removal of therapeutic drugs with a novel adsorbent system. Blood Purif. 2002; 20(4): 380-388. https://doi.org/10.1159/000063108

15. König C, Rohr A. C, Frey O. R. Brinkmann A. Roberts J. A. Wichmann D. et al. In vitro removal of anti-infective agents by a novel cytokine adsorbent system. Int J Artif Organs 2019; 42(2): 57-64. https://doi. org/10.1177/0391398818812601

16. Paterson IK, Hoyle A, Ochoa G, Baker-Austin C, Taylor NG. Optimising Antibiotic Usage to Treat Bacterial Infections. Sci Rep. 2016; 28(6): 37853. https://doi.org/10.1038/srep37853

17. Opatowski L, Mandel J, Varon E, Boëlle PY, Temime L, Guillemot D. Antibiotic dose impact on resistance selection in the community: a mathematical model of beta-lactams and Streptococcus pneumoniae dynamics. Antimicrob Agents Chemother. 2010; 54(6): 2330-2337. https://doi.org/10.1128/AAC.00331-09

18.Zoller M, Döbbeler G, Maier B, Vogeser M, Frey L, Zander J. Can cytokine adsorber treatment affect antibiotic concentrations? A case report. J Antimicrob Chemother. 2015; 70(7): 2169-2171. https://doi. org/10.1093/jac/dkv068

19. Poli EC, Simoni C, André P, Buclin T, Longchamp D, Perez M, et al. Clindamycin clearance during Cytosorb ${ }^{\star}$ hemoadsorption: A case report and pharmacokinetic study. Int J Artif Organs 2019; 42(5): 258-262. https://doi.org/10.1177/0391398819831303

20. Giuntoli L, Dalmastri V, Cilloni N, Orsi C, Stalteri L, Demelas V, et al. Severe quetiapine voluntary overdose successfully treated with a new hemoperfusion sorbent. Int J Artif Organs 2019 [ahead of print] https:// doi.org/10.1177/0391398819837686

21. Hassan K, Kannmacher J, Wohlmuth P, Budde U, Schmoeckel M, Geidel S. Cytosorb adsorption during emergency cardiac operations in patients at high risk of bleeding. Ann Thorac Surg. 2019; 108(1): 45-51. doi: 10.1016/j.athoracsur.2018.12.032

22. Warltier D, Laffey J, Boylan J, Cheng D. The Systemic Inflammatory Response to Cardiac Surgery: Implications for the Anesthesiologist. Anesthesiology 2002; 97(1): 215-252.

23. Träger K, Skrabal C, Fischer G, Datzmann T, Schroder J, Fritzler D, et al. Hemoadsorption treatment of patients with acute infective endocarditis during surgery with cardiopulmonary bypass - a case series. Int J Artif Organs. 2017; 40(5): 240-249. https://doi.org/10.5301/ijao.5000583

24. Nemeth E, Kovacs E, Racz K, Soltesz A, Szigeti S, Kiss N, et al. Impact of intraoperative cytokine adsorption on outcome of patients undergoing orthotopic heart transplantation-an observational study. Clin Transpl. 2018; 32(4): e13211. https://doi.org/10.1111/ctr.13211

25. Gleason TG, Argenziano M, Bavaria JE, Kane LC, Coselli JS, Engelman RM, et al. Hemoadsorption to Reduce Plasma Free Hemoglobin during Cardiac Surgery: Results of REFRESH I Pilot Study. Semin Thorac Cardiovasc Surg 2019 https://doi.org/10.1053/j.semtcvs.2019.05.006 [ahead of print]

26. Saller T, Hagl C, Woitsch S, Li Y, Niedermayer S, Born F. et al. Haemadsorption improves intraoperative haemodynamics and metabolic changes during aortic surgery with hypothermic circulatory 
arrest, European Journal of Cardio-Thoracic Surgery(2019). https://doi. org/10.1093/ejcts/ezz074 [ahead of print].

27. Kühne LU, Binczyk R, Rieß FC. Comparison of intraoperative versus intraoperative plus postoperative hemoadsorption therapy in cardiac surgery patients with endocarditis. Int J Artif Organs 2019; 42(4): 194-200. https://doi.org/10.1177/0391398819831301

28. Bernardi MH, Rinoesl H, Dragosits K, Ristl R, Hoffelner F, Opfermann $\mathrm{P}$, et al. Effect of hemoadsorption during cardiopulmonary bypass surgery - a blinded, randomized, controlled pilot study using a novel adsorbent. Crit Care. 2016; 20: 96. https://doi.org/10.1186/s13054-0161270-0

29. Poli EC, Alberio L, Bauer-Doerries A, Marcucci C, Roumy A, Kirsch $\mathrm{M}$, et al. Cytokine clearance with CytoSorb ${ }^{\circ}$ during cardiac surgery: a pilot randomized controlled trial. Crit Care. 2019; 23(1): 108. https:// doi.org/10.1186/s13054-019-2399-4

30. Hartmann J, Harm S. Removal of bile acids by extracorporeal therapies: an in vitro study. Int J Artif Organs 2018; 41(1): 52-57. https://doi. org/10.5301/ijao.5000643

31. Gemelli C, Cuoghi A, Magnani S, Atti M, Ricci D, Siniscalchi A, et al. Removal of Bilirubin with a New Adsorbent System: In Vitro Kinetics. Blood Purif. 2019; 47(1-3): 10-15. https://doi.org/10.1159/000492378

32. Singh A, Mehta Y, Trehan N. Bilirubin Removal Using CytoSorb Filter in a Cardiac Surgical Patient. J Cardiothorac Vasc Anesth. 2019; 33(3): 881-883. https://doi.org/10.1053/j.jvca.2018.08.213

33. Falthauser A, Kullmann F. Use of Hemoadsorption in a Case of Severe Hepatic Failure and Hyperbilirubinemia. Blood Purif. 2017; 44(2): 98-99. https://doi.org/10.1159/000470826

34. Dhokia VD, Madhavan D, Austin A, Morris CG. Novel use of Cytosorb $^{\text {st }}$ haemadsorption to provide biochemical control in liver impairment. J Intensive Care Soc. 2019; 20(2): 174-181. https://doi. org $/ 10.1177 / 1751143718772789$

35. Piwowarczyk P, Kutnik P, Potręć-Studzińska B, Sysiak-Sławecka J, Rypulak E, Borys M, et al. Hemoadsorption in isolated conjugated hyperbilirubinemia after extracorporeal membrane oxygenation support. Cholestasis of sepsis: A case report and review of the literature on differential causes of jaundice in ICU patient. Int J Artif Organs 2019; 42(5): 263-268. https://doi.org/10.1177/0391398819834012

36. Buttner S, Patyna S, Koch B, Finkelmeier F, Geiger H, Sarrazin C, et al. Application of Hemoadsorption in a Case of Liver Cirrhosis and Alcohol-Related Steatohepatitis with Preexisting Hepatitis C Infection. Blood Purif. 2017; 44(1): 30-31. https://doi.org/10.1159/000455064

37. Cirstoveanu CG, Barascu I, Mc Kenzie Stancu S. Hemadsorption with Adult CytoSorb ${ }^{\circ}$ in a Low Weight Pediatric Case. Case Rep Crit Care. 2017; 2017: 6987167. https://doi.org/10.1155/2017/6987167

38. Calabrò MG, Febres D, Recca G, Lembo R, Fominskiy E, Scandroglio AM, et al. Blood Purification With CytoSorb in Critically Ill Patients: Single-Center Preliminary Experience. Artif Organs 2019; 43(2): 189194. https://doi.org/10.1111/aor.13327

39. Frimmel S, Hinz M, Schipper J, Bogdanow S, Mitzner S, Koball S. Cytokine adsorption is a promising tool for therapy of hemophagocytic lymphohistiocytosis, Int J Artif Organs 2019. doi: 10.1177/0391398819857444 [ahead of print]

40. Milella L, Ficarella M. First Application of CVVHDF, Plasmapheresis and "Cytosorb Absorber" to Solve a Pediatric Haemophagocitic Histyocitosis Case. Res Pediatr Neonatol. 2017; 1(2). https://doi.org/ 10.31031/RPN.2017.01.000510

41. Khawaja MR, Manchanda N. Acquired Hemophagocytic Lymphohistiocytosis Among Adults: A Single Center Experience. Blood. 2013; 122(21): 2277. 